\title{
Relationship between the comfort level of chronic renal patients and sociodemographic and clinical variables
}

\author{
Relação do nível de conforto de pacientes renais crônicos com variáveis sociodemográficas e clínicas \\ Relación del confort de los pacientes renales crónicos con variables sociodemográficas y clínicas
}

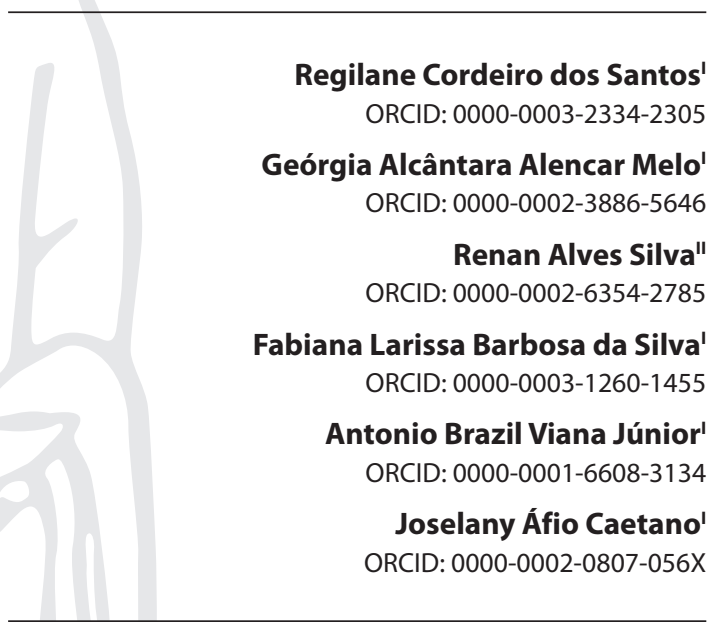

'Universidade Federal do Ceará. Fortaleza, Ceará, Brazil. "Universidade Federal do Espírito Santo. São Mateus, Espírito Santo, Brazil.

How to cite this article: Santos RC, Melo GAA, Silva RA, Silva FLB, Viana Júnior AB,

Caetano JA. Relationship between the comfort level of chronic renal patients and sociodemographic and clinical variables. Rev Bras Enferm. 2020;73(Suppl 5):e20200085. doi: http://dx.doi.org/10.1590/0034-7167-2020-0085

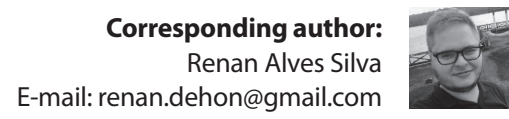

EDITOR IN CHIEF: Antonio José De Almeida Filho ASSOCIATE EDITOR: Hugo Fernandes

Submission: 06-21-2019

Approval: 06-05-2020

\begin{abstract}
Objective: To assess the association between the comfort level of chronic hemodialysis patients with sociodemographic and clinical variables using the General Comfort Questionnaire. Method: Cross-sectional study, with a quantitative approach, considering 180 chronic hemodialysis renal patients. Two instruments were used: one for sociodemographic and clinical variables; and the General Comfort Questionnaire, Brazilian version. Mann-Whitney's, Kruskal-Wallis's, and Spearman's tests were used for data analysis. Results: The overall comfort level of patients was $78.16 \%$. The socio-cultural domain presented the lowest level of comfort and the psychospiritual the highest level. Some variables were significantly associated with the domains, such as marital status, education, and considering oneself to be anxious. Conclusion: In the four domains of comfort, it was possible to identify patients' needs, such as the presence and intensity of pain, anxiety, constipation and type of access, making it possible to guide nurses in the systematization of care and improve the comfort of these patients.
\end{abstract}

Descriptors: Renal Insufficiency; Renal Dialysis; Patient Comfort; Health Evaluation; Nursing.

\section{RESUMO}

Objetivo: Correlacionar o nível de conforto de pacientes renais crônicos hemodialíticos por meio do General Comfort Questionnaire com as variáveis sociodemográficas e clínicas. Método: Estudo transversal, abordagem quantitativa, com 180 pacientes renais crônicos hemodialíticos. Utilizaramse dois instrumentos: um de caracterização sociodemográfica e clínica; e o General Comfort Questionnaire, versão brasileira. Para análise dos dados, foram usados os testes de MannWhitney, Kruskal-Wallis e o teste de Spearman. Resultados: O nível de conforto geral dos pacientes foi de $78,16 \%$. Os domínios que apresentaram menor e o maior nível de conforto, respectivamente, foram o sociocultural e o psicoespiritual. Algumas variáveis correlacionadas significantemente com os domínios foram: estado civil, escolaridade e considerar-se ansioso. Conclusão: Nos quatro domínios do conforto, permitiu-se identificar necessidades dos pacientes, como presença e intensidade de dor, ansiedade, constipação e tipo de acesso, tornando possível nortear os enfermeiros na sistematização do cuidado e melhorar o conforto desses pacientes.

Descritores: Insuficiência Renal; Diálise Renal; Conforto do Paciente; Avaliação em Saúde; Enfermagem.

\section{RESUMEN}

Objetivo: Correlacionar el nivel de confort de pacientes renales crónicos hemodialíticos por medio del General Comfort Questionnaire con las variables sociodemográficas y clínicas. Método: Estudio transversal, abordaje cuantitativo, con 180 pacientes renales crónicos hemodialíticos. Se utilizaron dos instrumentos: un de caracterización sociodemográfica y clínica; y el General Comfort Questionnaire, versión brasileña. Para análisis de los datos, han sido usados los testes de Mann-Whitney, Kruskal-Wallis y el test de Spearman. Resultados: El nivel de confort general de los pacientes ha sido de $78,16 \%$. Los dominios que presentaron menor y el mayor nivel de confort, respectivamente, han sido el sociocultural y el psicoespiritual. Algunas variables correlacionadas considerablemente con los dominios han sido: estado civil, escolaridad y considerarse ansioso. Conclusión: En los cuatro dominios del confort, permitió identificarse necesidades de los pacientes, como presencia e intensidad de dolor, ansiedad, constipación y tipo de acceso, volviendo posible nortear los enfermeros en la sistematización del cuidado y mejorar el confort de esos pacientes.

Descriptores: Insuficiencia Renal; Diálisis Renal; Conforto del Paciente; Evaluación en Salud; Enfermería. 


\section{INTRODUCTION}

Patients with chronic kidney disease undergoing hemodialysis (HD) experience a series of changes and limitations that affect biological, psychological, and social aspects of their lives ${ }^{(1)}$. The routine imposed by treatment is exhaustive, as patients go to dialysis clinics two or three times a week for three to four hours/ session $^{(2)}$. This compromises the performance of their daily and work activities, generating financial dependence, in addition to impacting their quality of life $(\mathrm{QoL})^{(3)}$.

In addition, the constant occurrence of complications during treatment, such as hypotension, nausea, cramps, vomiting, and dizziness, associated with physical fatigue and emotional problems ${ }^{(4)}$, impairs the comfort of the patients. Comfort is a complex, multidimensional construct and a basic human need ${ }^{(5)}$. Theorist Katharine Kolcaba defines comfort as the immediate experience of feeling strengthened through the basic human needs of relief, tranquility, and transcendence, which are addressed in four contexts of experience (physical, psycho-spiritual, sociocultural, and environmental) ${ }^{(6)}$.

Thus, comfort is related to the bodily sensations that the patient experiences (physical aspect); the sensations and perceptions of the inner self, that is, of self-esteem and self-concept (psycho-spiritual aspect); interpersonal relationships between the patient, family, and community (social aspect); and environmental characteristics related to the patient, such as temperature, color, or lighting (environmental aspect) ${ }^{(6)}$.

When the situations and contexts merge, the patient's holistic comfort is reached from the perspective of meeting their needs. These, along with the contexts of experience, guided the development of the General Comfort Questionnaire (GCQ), which was built by the theorist to measure the comfort of people in a general state of illness. It consists of 48 Likert-type items, whose response options range from 1 to 4, and the higher the score, the higher the comfort level(7).

Furthermore, the comfort construct is identified in the literature as a state, a process, an outcome, an action, or an intervention (for comfort $^{(8)}$. This intervention, in turn, is centered on the activities of nursing care, since providing comfort is a factor of care and a responsibility of nurses ${ }^{(9)}$.

This questionnaire was cross-culturally adapted, and its content was validated by specialists, considering the psychometric properties in the referred population of this study. However, there is an absence of studies that clinically validate this instrument, as well as predict the association of sociodemographic and clinical variables with the contexts of comfort. Thus, it is necessary to understand, in the midst of the complexity of the chronic condition, the relationships of demographic and clinical variables that negatively influence comfort contexts, in order to better intervene.

In this context, it is essential to use the GCQ to measure the level of comfort in each context, in order to identify implicit and explicit relationships that are not found in the relevant literature.

\section{OBJECTIVE}

To assess the relationship between the comfort level of chronic renal patients with sociodemographic and clinical variables using the General Comfort Questionnaire.

\section{METHODS}

\section{Ethical aspects}

The study was approved by the Research Ethics Committee of the Universidade Federal do Ceará.

\section{Design and place of study}

This is a cross-sectional study, with a quantitative approach. The research was carried out in three hemodialysis clinics, which attend the largest number of chronic kidney patients in the metropolitan area of Fortaleza.

\section{Population}

The study population consisted of all chronic kidney patients attended in the clinics mentioned.

\section{Criteria of inclusion and exclusion}

The inclusion criteria were: being a patient at the clinic with a hemodialysis treatment time of at least 12 months; being over 18 years old; presenting a score on the Glasgow Coma scale equal to 15; and having a preserved hearing acuity. Patients who had used anxiolytics within 24 hours prior to the application of the instrument were excluded.

\section{Sample}

The sample calculation was made using the formula for cross-sectional studies with finite populations, adopting a $95 \%$ confidence interval, with a significance level (Z) of 1.96, sampling error (e) of $0.05(5 \%)$ and a prevalence (p) of $50 \%$, since the prevalence of the studied population is not known. A population of 338 patients was considered as a reference. Therefore, the sample consisted of 180 patients.

\section{Study protocol}

For data collection, two instruments were used: one for characterizing the sample, with questions about sociodemographic and clinical variables; and the General Comfort Questionnaire (GCQ), a translated and adapted version for use in Brazil in chronic hemodialysis patients. Cronbach's alpha was 0.80 , indicating good questionnaire adequacy and excellent internal item consistency ${ }^{(10)}$. Both instruments were applied by two nephrologist nurses and one generalist nurse, who are participating authors of this study. The GCQ is structured in four domains - physical, sociocultural, environmental, and spiritual - with a minimum score of 48 and a maximum of 192.

In the physical domain, the following items are evaluated: I feel my body relaxed now; I don't want to exercise; My pain is hard to bear; I am constipated now; I don't feel healthy right now; I'm hungry; I am very tired; This chair (bed) hurts me; I feel good enough to walk; I feel uncomfortable because I am not dressed.

Regarding the socio-cultural domain, the items are: I feel useful because I am working hard; There are people I can trust when I 
need help; I feel dependent on others; Nobody understands me; I feel sad when I am alone; I have someone / people who make me feel cared for; I would like to see my doctor more often; The mood here makes me feel better; I feel out of place here; My friends remember me sending messages and calling; I need to be better informed about my health.

For the environmental domain: I have enough privacy; This environment is pleasant; The noise won't let me rest; I do not like it here; This environment makes me feel afraid; The temperature in this place is pleasant; This environment inspires me; My belongings are not here; This environment has a terrible smell; and It's easy to get around here.

About the psycho-spiritual domain, the items are: My condition makes me sad; I feel confident; I feel that my life is worthwhile; I feel satisfied because I know that I am loved; I feel motivated to do my best; My faith helps me not to be afraid; I am afraid of what is about to happen; I've been going through changes that make me feel uncomfortable; I can overcome my pain; I'm happy; My beliefs give me peace of mind; I feel out of control; I am alone, but not lonely; I feel at peace; I am depressed; I have been finding meaning in my life; I need to feel good again.

\section{Data collection}

The collection occurred between August 2017 and March 2018. The instruments were applied through interviews during dialysis therapy in the three shifts (morning, afternoon, and night), according to the functioning of the hemodialysis unit. The mean length of the interviews for the two instruments was 20 to 30 minutes.

\section{Analysis of results and statistics}

The data regarding the sociodemographic, clinical and GCQ variables were described and analyzed with the aid of the Statistical Package for the Social Sciences (SPSS) software, version 22.

Descriptive statistics, using mean and standard deviations, was used to characterize the sample. Mann-Whitney's and KruskalWallis's statistical tests were used to analyze the variables and the questionnaire. For all tests, a 95\% confidence interval ( $p$ $<0.05)$ was applied.

\section{RESULTS}

In the analysis of the sociodemographic profile, it was identified that 75 patients (41.7\%) were in the age group from 40 to 59 years, with a mean of 53.9 years. The majority were male (54.4\%), brown $(73.3 \%)$, catholic $(67.8 \%)$, and married (47.8\%). With regard to educational level, 107 (59.4\%) had eight years or less of study.

Regarding their source of income, it was found that 87 (48.3\%) depended on health welfare, with individual (84.4\%) and family incomes $(54.4 \%)$ of up to one minimum wage ( $R \$ 954,00)$. Most patients came from the metropolitan region (60.6\%), used public city transportation (37.8\%), and spent an hour or less (84.4\%) to get to the clinic.
As for the clinical profile of the patients, 124 (68.9\%) reported not feeling pain at the moment. For those with pain (31.7\%), moderate intensity pain (12.2\%) was the most common. Most reported not having diaphoresis (73.9\%), pruritus (65.6\%), or constipation (61.1\%); $77.2 \%$ still urinated; $58.3 \%$ were anxious; 92.2\% had an arteriovenous fistula (AVF); and $77.2 \%$ had been treating for hemodialysis for less than five years.

To investigate the general comfort of patients in relation to each domain of the GCQ, the mean score of the items in each subscale was calculated. It was observed that the domain with the lowest level of comfort was the sociocultural (31.13), and the one with the best level of comfort was the psycho-spiritual (55.51), even considering that the mean was divided by the number of questions in each domain. The sample had an overall comfort level of $78.16 \%$.
Table 1 - Measurements for comfort contexts, n= 180, Fortaleza, Ceará, Brazil, 2018

\begin{tabular}{lccccccc} 
Domains & Mean & $\begin{array}{c}\text { Standard } \\
\text { Deviation }\end{array}$ & Median & Minimum & $\begin{array}{c}\text { P25 } \\
\%\end{array}$ & $\begin{array}{c}\text { P75 } \\
\%\end{array}$ & Maximum \\
\hline Physical & 30.88 & 5.04 & 32.00 & 17.00 & 27.00 & 35.00 & 40.00 \\
Sociocultural & 30.24 & 5.19 & 31.00 & 18.00 & 26.00 & 34.00 & 42.00 \\
Environment & 31.13 & 5.00 & 32.00 & 14.00 & 28.00 & 35.00 & 40.00 \\
Psychospiritual & 55.51 & 6.48 & 56.00 & 34.00 & 52.00 & 61.00 & 67.00 \\
General comfort & 147.73 & 21.71 & 151 & 83 & 133 & 165 & 189 \\
\hline
\end{tabular}

As for the association of sociodemographic variables with general comfort, the variable"sex" showed a statistical difference $(p=0.035)$, according to which the male gender showed a higher mean of comfort (150.01 \pm 16.98$)$.

Regarding the association of clinical data with comfort, there is a statistical difference between comfort and the item "Feeling pain at the moment" $(p=0.034)$; regarding the intensity of pain $(p=0.045)$, patients who felt unbearable pain obtained a lower mean of comfort $(117.00 \pm 39.60)$. The change in sleep patterns caused by pain also showed a statistical difference $(p=0.003)$, with a higher mean of comfort in patients who did not have their sleep patterns change (149.14 \pm 14.19$)$. Anxiety was significant $(p=0.011)$, showing a higher mean of comfort among patients who did not consider themselves anxious (151.71 \pm 15.50$)$.

Pruritus in the body showed a significant difference $(p=0.052)$, as did constipation ( $p=0.007)$, with a better mean of comfort among patients without pruritus (149.08 \pm 18.31$)$ and non-constipated $(150.29 \pm 16,63)$. The type of vascular access also showed a significant difference $(p=0.035)$, with greater comfort being observed in patients with AVF (148.61 \pm 16.45$)$, as shown in Table 2.

When associating clinical variables with the physical domain, there was significance in patients who are in pain at the moment $(p=0.001)$; pain intensity $(p=-0.001)$; change in sleep patterns caused by pain $(p=-0.001)$; who had constipation $(p=0.003)$; and hemodialysis time (0.001). Regarding the socio-cultural domain, the correlated variables that showed significance were: change in the sleep pattern caused by pain $(p=0.018)$; marital status $(p=0.011)$; educational level ( $p=0.007)$; and source of income $(p=0.019)$. In the environmental domain, only the variables "consider yourself to be anxious" ( $p=0.004)$ and "type of access" ( $p=0.033)$ showed significance. Regarding the psychospiritual domain, the variables that showed significance were: educational level $(p=0.032)$, marital status $(p=0.047)$ and consider yourself to be anxious $(p=0.028)$. 
Table 2 - Association of clinical variables according to the mean General Comfort Questionnaire score of hemodialysis patients included in the study, $\mathrm{n}=180$, Fortaleza, Ceará, Brazil, 2018

\begin{tabular}{|c|c|c|}
\hline Variables & Mean \pm SD & $p<0.05$ \\
\hline Do you feel pain at the moment? & & $0.034^{1}$ \\
\hline Yes & $143.95 \pm 17.01$ & \\
\hline No & $149.66 \pm 16.63$ & \\
\hline How severe is the pain? & & $0.045^{2}$ \\
\hline Light & $147.71 \pm 18.38$ & \\
\hline Moderate & $146.14 \pm 14.03$ & \\
\hline Intense & $140.06 \pm 14.45$ & \\
\hline Unbearable & $117.00 \pm 39.60$ & \\
\hline $\begin{array}{l}\text { Has there been a change in the sleep } \\
\text { pattern caused by pain? }\end{array}$ & & $0.003^{1}$ \\
\hline Yes & $137.93 \pm 17.71$ & \\
\hline No & $149.14 \pm 14.19$ & \\
\hline Do you have diaphoresis? & & $0.131^{1}$ \\
\hline Yes & $145.32 \pm 15.48$ & \\
\hline No & $148.74 \pm 17.36$ & \\
\hline Do you consider yourself anxious? & & $0.011^{1}$ \\
\hline Yes & $145.10 \pm 17.41$ & \\
\hline No & $151.71 \pm 15.50$ & \\
\hline Do you have pruritus? & & $0.052^{1}$ \\
\hline Yes & $145.52 \pm 13.73$ & \\
\hline No & $149.08 \pm 18.31$ & \\
\hline Do you have constipation? & & $0.007^{1}$ \\
\hline Yes & $144.01 \pm 16.77$ & \\
\hline No & $150.29 \pm 16.63$ & \\
\hline Do you have diuresis? & & $0.098^{1}$ \\
\hline Yes & $149.04 \pm 15.99$ & \\
\hline No & $143.80 \pm 19.41$ & \\
\hline Type of access? & & $0.035^{1}$ \\
\hline Cateter & $138.79 \pm 20.21$ & \\
\hline Arteriovenous fistula & $148.61 \pm 16.45$ & \\
\hline
\end{tabular}

Table 3 - Association between clinical variables and comfort level per domain of the General Comfort Questionnaire, n= 180, Fortaleza, Ceará, Brazil, 2018

\begin{tabular}{|c|c|c|}
\hline & Mean \pm SD & $p<0.05$ \\
\hline \multicolumn{3}{|l|}{ Physical domain } \\
\hline Do you feel pain at the moment? & & $0.001^{1}$ \\
\hline Yes & $28.98 \pm 5.06$ & \\
\hline No & $31.76 \pm 4.80$ & \\
\hline How severe is the pain? & & $0.001^{2}$ \\
\hline Light & $30.43 \pm 4.57$ & \\
\hline Moderate & $30.14 \pm 5.20$ & \\
\hline Intense & $26.89 \pm 3.80$ & \\
\hline Unbearable & $21.00 \pm 4.24$ & \\
\hline $\begin{array}{l}\text { Has there been a change in the } \\
\text { sleep pattern caused by pain? }\end{array}$ & & $0.001^{1}$ \\
\hline Yes & $27.43 \pm 5.36$ & \\
\hline No & $30.25 \pm 4.22$ & \\
\hline Do you have diaphoresis? & & $0.587^{1}$ \\
\hline Yes & $30.30 \pm 5.55$ & \\
\hline No & $31.08 \pm 4.86$ & \\
\hline Do you consider yourself anxious? & & $0.154^{1}$ \\
\hline Yes & $30.34 \pm 5.21$ & \\
\hline No & $31.63 \pm 4.72$ & \\
\hline Do you have constipation? & & $0.003^{1}$ \\
\hline Yes & $29.41 \pm 5.48$ & \\
\hline No & $31.81 \pm 4.53$ & \\
\hline Type of access? & & $0.073^{1}$ \\
\hline Cateter & $28.43 \pm 5.75$ & \\
\hline Arteriovenous fistula & $31.08 \pm 4.94$ & \\
\hline Hemodialysis time & & $0.001^{2}$ \\
\hline$>5$ years & $31.32 \pm 4.60$ & \\
\hline 5 to 10 years & $31.72 \pm 4.71$ & \\
\hline$>10$ Years & $25.44 \pm 6.14$ & \\
\hline
\end{tabular}

Table 3 (concluded)

\begin{tabular}{|c|c|c|}
\hline & Mean \pm SD & $p<0.05$ \\
\hline \multicolumn{3}{|l|}{ Sociocultural domain } \\
\hline $\begin{array}{l}\text { Has there been a change in the } \\
\text { sleep pattern caused by pain? }\end{array}$ & & $0.018^{1}$ \\
\hline Yes & $27.75 \pm 4.38$ & \\
\hline No & $30.39 \pm 4.22$ & \\
\hline Marital status & & $0.011^{2}$ \\
\hline Married / stable union & $31.17 \pm 4.90$ & \\
\hline Single & $28.91 \pm 5.51$ & \\
\hline Widow & $28.63 \pm 4.84$ & \\
\hline Educational level & & $0.007^{2}$ \\
\hline$\leq 8$ years & $29.22 \pm 5.00$ & \\
\hline 9 to 12 years & $31.53 \pm 5.08$ & \\
\hline$\geq 13$ years & $33.57 \pm 5.74$ & \\
\hline Source of income & & $0.019^{2}$ \\
\hline Without income & $27.33 \pm 3.52$ & \\
\hline Retired & $31.05 \pm 4.37$ & \\
\hline Health welfare & $29.62 \pm 5.58$ & \\
\hline Works & $32.33 \pm 5.80$ & \\
\hline \multicolumn{3}{|l|}{ Environmental domain } \\
\hline Individual income & & $0.444^{1}$ \\
\hline Up to 1 minimum wage & $30.16 \pm 5.15$ & \\
\hline$>1$ minimum wage & $31.06 \pm 5.76$ & \\
\hline Type of access & & $0.033^{1}$ \\
\hline Cateter & $27.71 \pm 6.46$ & \\
\hline Arteriovenous fistula & $30.45 \pm 5.04$ & \\
\hline $\begin{array}{l}\text { Type of transportation used to go } \\
\text { to the clinic }\end{array}$ & & $0.936^{2}$ \\
\hline On foot & $30.92 \pm 4.83$ & \\
\hline By car & $31.09 \pm 4.45$ & \\
\hline By Motorcycle & $29.33 \pm 8.41$ & \\
\hline By bus & $30.93 \pm 5.43$ & \\
\hline $\begin{array}{l}\text { Through public transportation } \\
\text { offered by the city }\end{array}$ & $31.44 \pm 5.11$ & \\
\hline Do you have diaphoresis? & & $0.434^{1}$ \\
\hline Yes & $30.06 \pm 4.83$ & \\
\hline No & $30.30 \pm 5.33$ & \\
\hline Do you consider yourself anxious? & & $0.004^{1}$ \\
\hline Yes & $30.29 \pm 4.90$ & \\
\hline No & $32.31 \pm 4.92$ & \\
\hline \multicolumn{3}{|l|}{ Psychospiritual domain } \\
\hline Religion & & $0.983^{2}$ \\
\hline Catholic & $55.53 \pm 6.62$ & \\
\hline Evangelic & $55.75 \pm 6.29$ & \\
\hline Umbanda & $56 \pm 0$ & \\
\hline Educational level & & $0.008^{2}$ \\
\hline$\leq 8$ years & $54.43 \pm 6.59$ & \\
\hline 9 to 12 years & $57.39 \pm 6.04$ & \\
\hline$\geq 13$ years & $56.71 \pm 5.50$ & \\
\hline Marital status & & $0.047^{2}$ \\
\hline Married / stable union & $56.52 \pm 6.06$ & \\
\hline Single & $54.39 \pm 6.32$ & \\
\hline Widow & $53.69 \pm 8.81$ & \\
\hline Do you consider yourself anxious? & & $0.028^{1}$ \\
\hline Yes & $54.71 \pm 6.61$ & \\
\hline No & $56.85 \pm 6.13$ & \\
\hline
\end{tabular}

\section{DISCUSSION}

When evaluating the QCG aspects, patients showed greater impairment of the socio-cultural domain, reiterating harmful aspects of CKD and hemodialysis in the comfort of patients with regard to interpersonal, family, and socioeconomic relationships. The presence of CKD promotes several changes in patient behavior, such as in interpersonal relationships, which are more limited, as 
the subjects feel embarrassed and are ashamed of their image in front of other people ${ }^{(11)}$.

Therefore, in the sociocultural domain, the variables that were associated with the comfort level were: source of income, marital status, educational level, and change in sleep patterns caused by pain. The association of the variable"source of income" with the level of comfort was evidenced by the fact that patients who still work have a better level of comfort $(32.33 \pm 5.80)$ when compared with those who have no income, are retired, and receive health welfare. This is because chronic kidney disease causes several important limitations to patients, leading to work leaves and early retirements ${ }^{(12)}$.

Low socioeconomic status can be considered a risk factor for chronic diseases. In relation to CKD, it may be associated with difficulties in accessing the health system and with an inadequate control of diseases such as hypertension and diabetes. The social inequalities evidenced by the high degree of poverty and low level of education in the Northeast region, specifically, can negatively contribute to the development of CKD ${ }^{(13)}$.

Marital status and educational level had significant results in two domains: sociocultural and psychospiritual. These can be justified by the fact that living with a companion seems to enable the individual to adhere better to the treatment, because, through support, the treatment routine becomes easier to deal with ${ }^{(14)}$, which justifies the higher comfort among patients in such relations.

Regarding education, a lower number of years of study can interfere in the search for health services, as well as in the adherence and treatment of chronic diseases, generating complications and worsening health regarding chronic kidney disease. A study showed that the highest prevalence of chronic diseases is found in the most vulnerable populations and with the lowest level of education, since these people make little use of health services ${ }^{(15)}$.

The aspect that also revealed the lowest level of comfort was the environmental domain, which involves factors related to lighting, noise, equipment (furniture), color, temperature, and natural versus synthetic elements in the surroundings ${ }^{(16)}$.

Therefore, the variables that were significant when correlated with this domain were: type of access and consider being anxious. Patients using a catheter showed a lower level of comfort. The presence of apparent vascular accesses such as the catheter causes significant damage to patient self-image and sexuality, as well as discomfort in a sensitive region when inserted in the jugular or in an intimate region like the femoral vein. The fact of having a chronic disease with no possibility of cure and needing dialysis associated with an AVF or catheters to survive ends up generating social isolation and disinterest in affective relationships $^{(17)}$, a fact that can compromise comfort in the environment.

Anxiety was related to the level of comfort in the environmental and psychospiritual domains: patients who considered themselves anxious had a lower level of comfort, and prevalence in dialysis patients varies between $13 \%$ and $50 \%{ }^{(18)}$. This symptom proved to be a factor that specifically interferes with the environmental and psychospiritual comfort of patients on hemodialysis. Regarding the environment, the hemodialysis clinic often causes fear in patients due to the sound signals linked to the complications that can occur in the sessions; as well as due to the discomfort caused by the chair, leading the individual to become impatient and / or anxious to conclude the session ${ }^{(19)}$.
A study that investigated the association between psychological symptoms, such as depression, anxiety, stress, and quality of life in hemodialysis patients, pointed at anxiety as the most common psychological symptom in these patients, with an important impact on the life of renal patients undergoing hemodialysis ${ }^{(20)}$.

The third domain in the comfort level sequence was the physical, which involves the physiological mechanisms that are interrupted due to a disease or to invasive procedures ${ }^{(16)}$. In this domain, the changes that were associated with comfort were: feeling pain at the moment, pain intensity, change in sleep patterns caused by pain, constipation, and hemodialysis time.

Patients who do not feel pain have a higher mean of general comfort when compared to those who do. Pain interferes in the physical context due to bodily sensations ${ }^{(16)}$. For example, the positioning of patients during HD sessions affects physical comfort. However, in hemodialysis, this type of comfort is very much related to invasive procedures, such as the insertion of needles in patients with AVF. Pain caused by the insertion of needles in the AVF is considered a common and unavoidable problem with this method ${ }^{(21)}$.

Another pain complaint frequently mentioned by patients is the headaches. Their relationship with hemodialysis is observed right at the beginning of treatment, which may be accompanied by other symptoms such as nausea, vomiting, and arterial hypertension $^{(22)}$.

Almost half of patients who experience pain classify its intensity from moderate to severe ${ }^{(23)}$. A similar fact was found in this study: almost half of the patients who felt pain reported moderate intensity, followed by intense. In the physical context, unbearable pain presented a worse level of comfort.

Persistent pain can impair sleep, decrease memory, compromise physical status, and decrease social activities ${ }^{(24)}$. When correlating the change in the sleep pattern caused by pain with comfort in the physical and sociocultural domains, statistical significance was observed, with the highest mean of comfort among patients who had no change in sleep.

Another symptom that showed a significant relation with the physical domain was intestinal constipation. In the present study, this variable was found in $38.9 \%$ of patients. Although most still urinate, it was found that $78.3 \%$ of the interviewed patients drink less than a litre of water per day, due to medical restrictions, thus favoring intestinal constipation.

The cause of this symptom in chronic renal patients may be associated with some factors inherent to this population, such as emotional, pathological, physical, and medication-related factors; however, it is mainly due to eating habits such as reduced fiber and fluid intake. Many foods with a high level of fiber are also rich in potassium, which is why patients are advised to avoid them ${ }^{(25)}$.

The domain of the GCQ with the highest score was the psychospiritual, which has a connection with the internal awareness of oneself, including sexuality, the meaning of one's own life, and the relationship of someone with a higher order or being ${ }^{(16)}$. This domain was associated with the level of comfort in variables common to other domains, such as educational level and marital status, in the sociocultural one; and as considering oneself anxious, in the environmental one.

Therefore, it is suggested that the presence of a partner, years of study, as well as the feelings that are generated in the face of 
the limitations and exhaustive routines imposed by hemodialysis treatment, interfere with patient comfort in several aspects. This requires the team of professionals working in hemodialysis centers to offer means to improve comfort through social support, to promote increased interaction between professionals and patients, as well as to mediate interventions to improve sleep and strengthen faith and spirituality in these individuals.

\section{Study limitations}

The limitations of this study were: the gap in the literature of studies that used the QCG to measure the comfort of chronic renal patients and the fact that this study took place in a single regional location, which restricts the generalization of the results.

\section{Contribution to the field of Nursing, Health, or Public Policy}

This research found that the GCQ is a useful questionnaire to assess the level of comfort in general and in specific contexts, favoring the reorientation of actions before, during and after hemodialysis, as well as the relationship with possible negative variables that interfere with comfort.

Thus, the results of this study enable nurses to direct and strengthen the nursing process for chronic renal patients, who depend on renal replacement therapy, through the evaluation and promotion of comfort, using a specific validated questionnaire capable of describing, explaining, and predicting this phenomenon.

Thus, it is noted that the use of this instrument makes it possible to identify the intervening needs for comfort, directing its promotion through interventions based on the contextual reality in which the patient is inserted. This can be done through socialization and social support by relatives and other members, strengthening bonds, providing health guidance aimed at changing inappropriate behaviors, reducing intradialitic and interdialitic complications, reducing anxiety, increasing selfesteem and self-concept, promoting the development of coping strategies, mood control, resilience and environmental control, all aimed at guaranteeing the quality and safety of care.

Thus, this study suggests a new look at of the chronic renal patient undergoing hemodialysis, including aspects that can be better guaranteed in care, such as the use of direct or indirect interventions.

\section{CONCLUSION}

It was possible to identify, in the four domains of comfort, the patients' needs, such as the presence and intensity of pain, anxiety, constipation, and type of access, making it possible to guide nurses in the systematization of care, considering which domains need to be improved for the comfort of these patients.

Also, it was found that the application of the GCQ, an empirical indicator of Kolcaba's theory, is useful to identify the comfort levels of hemodialysis patients in the different contexts of the theory and serves to understand which aspects negatively influence their level of comfort, such as sex, marital status, presence of pain, anxiety, pruritus, constipation, and type of access.

The present study found that, among contexts or domains, sociocultural comfort showed a lower mean, justified by changes in self-image and social life, common in renal patients, while the psychospiritual domain was the one with the best level of comfort. Through these results, the nurse can learn what are the comfort-related demands that require actions to be implemented to reach a satisfactory level of comfort, aiming to improve the wellbeing of these patients.

This research may also favor the realization of new investigations related to the comfort of renal patients, supporting the implementation of new therapeutic approaches that can improve the living conditions of these patients.

\section{REFERENCES}

1. Silva SM, Braido NF, Ottaviani AC, Gesualdo GD, Zazzetta MS, Orlandi FS. Social support of adults and elderly with chronic kidney disease on dialysis. Rev Latino-Am Enfermagem. 2016;24:e2752. doi: 10.1590/1518-8345.0411.2752

2. Zazzeron L, Pasquinellia G, Nannib E, Cremoninib V, Rubbib I. Comparison of Quality of life in patients undergoing hemodialysis and peritoneal dialysis: a systematic review and meta-analysis. Kidney Blood Press Res. 2017;42:717-727. doi: 10.1159/000484115

3. Oliveira APB, Schmidt DB, Amatneeks TM, Santos JC, Cavallet LHR, Michel RB. Quality of life in hemodialysis patients and the relationship with mortality, hospitalizations and poor treatment adherence. J Bras Nefrol. 2016;28(4):411-20. doi: 10.5935/0101-2800.20160066

4. International Society of Nephrology. Global Kidney Health Atlas: a report by the International Society of Nephrology on the current state of organization and structures for kidney care across the globe. Brussels, Belgium, 2017.

5. Freitas KS, Menezes IG, Mussi FC. Validation of the Comfort scale for relatives of people in critical states of health. Rev Latino-Am Enfermagem. 2015;23(4):660-8. doi: 10.1590/0104-1169.0180.2601

6. Kolcaba K. Definitions of concepts in Kolcaba's middle range: theory of comfort [Internet]. 2010 [cited 2018 Nov 28]. Available from: http:// www.thecomfortline.com/home/faq.html

7. Góis JA, Freitas KS, Kolcaba K, Mussi FC. Cross-cultural adaptation of the General Comfort Questionnaire to Brazilian patients with myocardial infarction. Rev Bras Enferm. 2018;71(6):2998-3005. doi: 10.1590/0034-7167-2017-0557

8. Pinto S, Fumincelli L, Mazzo A, Caldeira S, Martins JC. Comfort, well-being and quality of life: discussion of the differences and similarities among the concepts. Porto Biomed J. 2017;2(1):6-12. doi: 10.1016/j.pbj.2016.11.003

9. Ribeiro PCPSV, Marques RMD, Ribeiro MP. Geriatric care: ways and means of providing comfort. Rev Bras Enferm. 2017;70(4):865-72. doi: 10.1590/0034-7167-2016-0636 
10. Melo GAA, Silva RA, Pereira FGF, Caetano JA. Adaptação cultural e confiabilidade do General Comfort Questionnaire para pacientes renais crônicos no Brasil. Rev Latino-Am Enfermagem. 2017;25:e2963. doi: 10.1590/1518-8345.2280.2963

11. Bibiano RS, Souza CA, Silva AC. A percepção da autoimagem do cliente renal crônico com cateter temporário de duplo lúmen. Revista Pró-UniverSUS[Internet]. 2015 [cited 2018 Dec 22];5(1):5-1. Available from: http://editora.universidadedevassouras.edu.br/index.php/RPU/ article/view/792/60

12. Cosson IO, Gomes GM, Gomes AA, Silva KV. Profile of patients in renal replacement therapy in nephrology unit. Rev Enferm UFPE. 2014;8(Supl. 2):3693-9. doi: 10.5205/reuol.4597-37683-1-ED.0810supl201416

13. Nunes MB, Santos EM, Leite MI, Costa AS, Guihem DB. Epidemiological profile of chronic kidney patients on dialysis program. Rev Enferm UFPE. 2014:8(1):69-76. doi: 10.5205/reuol.4843-39594-1-SM.0801201410

14. Medeiros RC, Sousa MNA, Santos MLL, Medeiros HRL, Freitas TD, Moraes JC. Epidemiological profile of patients under hemodialysis. Rev Enferm UFPE. 2015;9(11):9846-52. doi: 10.5205/reuol.8008-72925-1-ED.0911201527

15. Malta DC, Bernal RTI, Lima MG, Araújo SSC, Silva MMA, Freitas MIF, et al. Doenças crônicas não transmissíveis e a utilização de serviços de saúde: análise da Pesquisa Nacional de Saúde no Brasil. Rev Saude Publica. 2017;51(Supl1):10s. doi: 10.1590/S1518-8787.2017051000090

16. Kolcaba K. Comfort Theory and Practice: a vision for holistic health care and research. Springer Publishing Company: New York, 2003.

17. Silva PFC, Pires AS, Gonçalves FGA, Cunha LP, Campos TS, Noronha IR. Influence of vascular accesses on the self-image and sexuality of patients undergoing hemodialysis: contribution to nursing. Cienc Cuid Saude. 2017;12(1):1-7. doi: 10.4025/cienccuidsaude.v16i1.34402

18. Loosman WL, Haverkamp GLG, Beukel TOV, Hoekstra T, Dekker FW, Shaw PKC, et al. Depressive and anxiety symptoms in Dutch immigrant and native dialysis patients. J Immigr Minor Health. 2018;20(6):1339-46. doi: 10.1007/s10903-018-0722-9

19. Grebin SZ, Echeveste MES, Magnago PF, Tanure, RLZ, Pulgati FH. Estratégia de análise para avaliação da usabilidade de dispositivos médicos na percepção do usuário: um estudo com pacientes em tratamento de hemodiálise. Cad Saúde Pública [Internet]. 2018 [cited 2019 Oct 10];34(8):1-15. Available from: http://www.scielo.br/pdf/csp/v34n8/1678-4464- csp-34-08-e00074417.pdf

20. Bujang MA, Musa R, Liu WJ, Chew TF, Lim CTS, Morad Z. Depression, Anxiety and stress among patients with dialysis and the association with quality of life. Asian. J Psychiatr. 2015;18:49-52. doi:10.1016/j.ajp.2015.10.004

21. Ghoreyshi Z, Amerian M, Amanpour F, Ebrahimi H. Evaluation and comparison of the effects of xyla-p cream and cold compress on the pain caused by the cannulation of arteriovenous fistula in hemodialysis patients. Saudi J Kidney Dis Transpl[Internet]. 2018[cited 2019 Feb 14];29:369-75. Available from: http://www.sjkdt.org/text.asp?2018/29/2/369/229265

22. Moraes AP, Salomão CEM, Soares FHC, Sousa KS, Moraes TC, Silva MHS, Pimentel AL. Prevalência de cefaleia em uma unidade de diálise. Rev Interdiscip Estud Exper[Internet]. 2016[cited 2019 Feb 14];8:23-30. Available from: https://riee.ufjf.emnuvens.com.br/riee/article/ view/2883/1080

23. Koncicki HM, Schell JO. Communication skills and decision making for elderly patients with advanced kidney disease: a guide for nephrologists. Am J Kidney Dis. 2016;67(4):688-695. doi: 10.1053/j.ajkd.2015.09.032

24. Vides MC, Martins MR. Bone pain assessment in patients with chronic kidney disease undergoing hemodialysis. Rev Dor. 2017;18(3):245-9. doi: 10.5935/1806-0013.20170109

25. Tinôco JDS, Paiva MGMN, Lúcio KDB, Pinheiro RL, Macedo BM, Lira ALBC. Complications in patients with chronic renal failure undergoing hemodialysis. Cogitare Enferm. 2017;22(4):e52907. doi: 10.5380/ce.v22i4.52907 